\title{
What Chinese Provinces Export Matter for Their Income and Export Performance
}

\author{
Joachim Jarreau ${ }^{\mathrm{a}}$ and Sandra Poncet ${ }^{\mathrm{a}^{\mathrm{*}}}$
}

${ }^{a}$ Paris School of Economics, Université de Paris 1 Panthéon-Sorbonne and CEPII

\begin{abstract}
We estimate the relationship between export sophistication and economic and export performance in China. We confirm Hausmann, Hwang and Rodrik (2007)'s prediction that regions that develop more sophisticated goods grasp greater gains from globalization and grow faster. We find that these gains are limited to export activities undertaken by domestic entities. Direct gains do not appear to derive from foreign entities typically engaged in processing trade even though they are the main contributors to the global upgrading of China's exports.
\end{abstract}

JEL Classifications: F1, O1, R1

Keywords: Export sophistication, economic growth, outward orientation, China

\section{Introduction}

In the past two decades, Chinese exports have more than quintupled between 1992 and 2007, faster than the growth rate of the economy. China's economy has shifted over this period from an isolated position with exports representing less than $10 \%$ of GDP in 1980 to a highly integrated one, with an export ratio of more than $37 \%$ in 2007 . This process has been accompanied by a not less impressive diversification of China's trade, as its manufactured exports pervaded all sectors of world trade, from low-technology textile to high-tech electronics and computers.

One important debate has emerged with the apparent upgrading of China's exports concerning its contribution to economic development. The issue is whether reshaping the production structure beyond the boundaries set by factor endowments (physical capital, human capital and natural resources) provides some benefits. According to the standard trade theory focusing on comparative advantages the answer is clearly no. An important theoretical literature pertaining to endogenous growth has however proposed models going beyond the traditional framework of perfect competition to show that

\footnotetext{
* We thank an anonymous referee for valuable comments. We are grateful to seminar participants at the 2010 APJAE Symposium on International Trade and the China Economy for helpful discussions and suggestions. This work has been supported by the CEPREMAP Progam 5.
} 
production structure is an important contributor to economic performance, thus that developing countries could gain from importing and adopting technology from more advanced economies. These models focus on the process of learning and adoption of new technologies as a costly process. In this framework, patterns of comparative advantage across countries will depend not only on their respective endowments, but also on the national policies encouraging technological learning and technology import. Some empirical validation of these theories has been recently provided by Hausmann, Hwang and Rodrik (2007). Based on cross-country panel regressions, they show that countries that acquire the capability to export a basket of products of higher productivity (given their initial factor endowments) will gain more from trade and achieve higher growth rates. They hence argue that "what a country exports matters". This paper relies on very detailed trade data for 30 provinces within China over the period 1997-2007 to empirically investigate the contribution of China's export upgrading to explain its recent income and export growth.

This paper relies on provincial trade data differentiating between domestic and foreign trading units and between processing trade and ordinary trade to contribute to the literature in two different ways.

First, we precisely estimate the upgrading of China's exports by disentangling between indigenous sophistication and foreign sophistication. We find that the recent upgrading of China's trade has also concerned domestic producers operating in the ordinary trade sector. The per capita income level associated to exports by domestic entities has increased by $34.7 \%$ between 1997 and 2007 to reach $12500 \$$, similar to that of Lithuania, a country three times richer in PPP per capita terms than China. It remains however lower than that of foreign entities that has risen by $41.6 \%$ over the period to reach $14550 \$$, similar to the income level associated to the export bundle of Italy, a country five times richer in PPP per capita terms than China. The decomposition of China's export sophistication growth highlights that an overwhelming share $(85 \%)$ can be attributed to non-domestic entities, in line with previous findings of the key role of processing trade in export upgrading (Lemoine and Unal-Kesenci, 2004; Amiti and Freund, 2008). Wang and Wei (2008) relying on city-level data show that processing trade and foreign investment are conducive to the export of more sophisticated varieties within a given product category.

Second, we estimate the relationship between export sophistication and economic performance in China. We confirm Hausmann, Hwang and Rodrik (2007)'s prediction that regions that engage in the cost discovery process of developing higher productivity goods grasp greater gains from globalization and grow faster. An important question in the Chinese context is whether these growth enhancing effects depend on the origin (domestic or foreign) of this cost discovery process. This has profound implications on the capacity of a region to jumpstart development by relying on Foreign Direct Investment (FDI) attraction and processing trade instead of indigenous R\&D promotion. We find that these gains are limited to activities undertaken by domestic entities. No growth enhancing gains are found to derive from foreign entities, which are typically engaged in processing trade. This contrasts sharply with the fact that the increase in the level of sophistication of foreign entities is the main contributor to the global upgrading of China's exports. 
The rest of this article is organized as follows. In Section 2, we present our measure of export sophistication and the dataset used and we describe the recent evolution of China's export sophistication. Section 3 illustrates our baseline specification and estimation methodology. Section 4 presents our main empirical results. Section 5 concludes.

\section{Evolution of China's trade structure}

\subsection{Measuring export sophistication}

We rely on Hausmann, Hwang and Rodrik (2007)'s measure of the productivity of a country's export basket, obtained by comparing it with the income level of countries with similar export structures. This measure assumes that each good $k$ that a country can potentially produce and export has an intrinsic level of productivity associated to it, $P R O D Y_{k}$. PRODY $Y_{k}$ denotes the product sophistication level of good $k$ and is measured as the weighted average of the real GDP per capita $\left(Y_{j}\right)$ of all countries $j$ that export good $k$. The weight variable is $\frac{x_{j k} / X_{j}}{\sum_{j}\left(x_{j k} / X_{j}\right)}$, where $x_{j k}$ is the value of exports of good $k$ by country $j$ and $X_{j}$ is the total value of country $j$ 's exports, so that the weight variable reflects the importance of good $\mathrm{k}$ in country $\mathrm{j}$ 's exports relative to all the other countries that export the good. We have:

$$
\operatorname{PRODY}_{k}=\sum_{j} \frac{x_{j k} / X_{j}}{\sum_{j}\left(x_{j k} / X_{j}\right)} Y_{j}
$$

where $X_{j}$ is the per capita level of income of country $j$, measured as the real GDP in PPP, per capita. The bigger share a given good $k$ weighs in the exports of rich countries, the more 'sophisticated' it will be.

Similarly, a country's export sophistication level can be computed as the weighted average of the sophistication levels of all goods exported by the country. Hence, the overall level of export sophistication of country $j$ is the weighted sum of the productivity levels associated to each exported good $k, P R O D Y_{k}$, with the weights being the share of each good in the country's total exports.

$$
E X P Y_{j}=\sum_{k} \frac{x_{j k}}{X_{j}} P R O D Y_{k}
$$

The purpose of this measure is not to determine directly the intrinsic features that make a product sophisticated, e.g. the technology embedded in it, the levels of specialized skills required to produce it, R\&D investments, etc.; but rather to infer, from observed patterns of trade, which products require a high level of development to export.

As a robustness test, we will rely on an alternative indicator of sophistication based on Lall (2000)'s classification of products by technological level: the share of hightechnology manufactures in total exports. We hold this share as a more precise indicator 
of high technology since it is focused on the top of the quality/technology spectrum. Also it is strictly related to technology contrary to EXPY, which cannot be held as strictly measuring technology as it possibly takes into account other aspects which make a given product likely to be exported by advanced, technology-rich countries. We will show that our results are confirmed.

\subsection{Data}

We compute the product level sophistication index, $P R O D Y_{k}$, for each year between 1997 and 2007 from the BACI world trade dataset. ${ }^{1}$ This dataset, which is constructed using COMTRADE original data, proposes bilateral trade flows at the 6-digit product (Gaulier and Zignago, 2008). ${ }^{2}$ We construct yearly sophistication measures for international partners and for Chinese provinces ${ }^{3}$ based on Equation 2. Our main source for this study is the Chinese customs data, which report province level exports and imports by 6-digit product over the period 1997-2007. Its unique feature is that it allows differentiating between domestic and foreign trading units ${ }^{4}$ and between processing trade and ordinary trade. Processing trade includes all trade flows by firms operating in the assembly sector, that is, importing inputs to process them in China and reexport the finished products (these producers benefit from a preferential tax regime on imported inputs). Ordinary trade relates to normal exports. ${ }^{5}$ We are thus able to compute $E X P Y_{j}^{f}=\sum_{k} \frac{x_{j k}^{f}}{X_{j}^{f}} P R O D Y$ where $f$ denotes the firm type (domestic and foreign) and $j$ the province, separately for processing and ordinary transactions.

\section{Evidence on China's export sophistication}

\subsection{China's upgrading: domestic versus non-domestic}

When we look of the evolution of China's sophistication over time distinguishing between domestic and foreign entities, we observe that the recent upgrading of China's exports is not confined to foreign entities typically operating in processing trade but has also concerned domestic producers. Figure 1 displays a steep increase in the sophistication level of exports for both types of exporters. The income level associated to exports by domestic entities has increased by $34.7 \%$ between 1997 and 2007. Over the same period that of nondomestic entities has however risen faster, by $41.6 \%$. The

\footnotetext{
${ }^{1}$ World countries real GDP per capita in PPP are taken from the World Development Indicators database (World Bank).

${ }^{2}$ The Chinese customs data was converted into the 1992 Harmonized system (HS) classification before being merged with the BACI data that uses the 1992 classification for all years.

${ }^{3}$ Chinese provinces' real GDP per capita come from the China Statistical Yearbook.

${ }^{4}$ Foreign firms include fully-foreign firms as well as "joint ventures" regrouping several contractual forms, including equity and non-equity joint ventures, and joint cooperatives.

${ }^{5}$ The data also refer to a third ("Others") category that is dropped. It groups other flows such as aid, border trade and consignment.
} 
level of sophistication for domestic entities is systematically lower than that of nondomestic exporters, certainly reflecting their different involvement in assembly trade (Lemoine and Unal-Kesenci, 2004; Amiti and Freund, 2008). In 2007, 78\% of nondomestic firms exports correspond to processing trade activities, compared to $23 \%$ for domestic firms exports. In 2007, an overwhelming share of China's processing trade exports (82\%) emanate from non-domestic firms. Over the period (1997-2007), the gap between domestic and foreign export sophistication has thus doubled from $\$ 1,025$ to $\$ 2,090$.

\section{Figure 1: China's export Sophistication: evolution according to firm type}

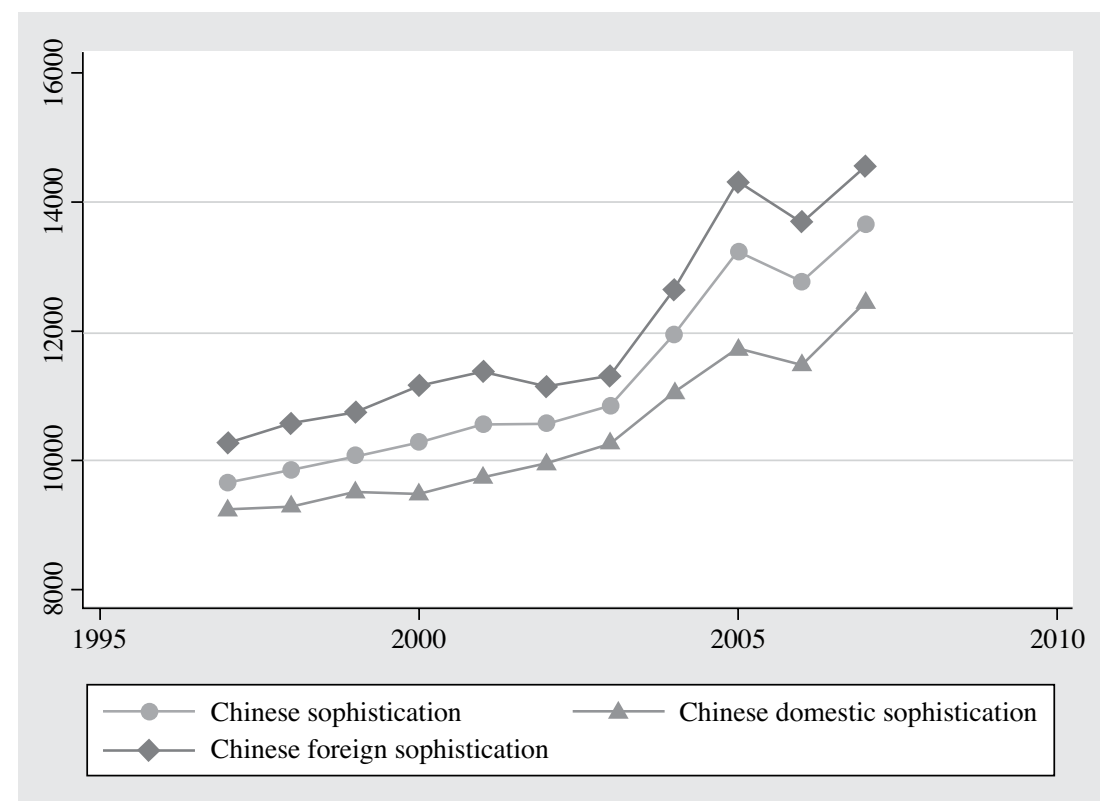

Source: Authors' computations based on Chinese Customs, BACI and WDI.

When decomposing the growth in global sophistication, we find that $85 \%$ of it can be attributed to non-domestic entities. A similar and even clearer message is delivered when relying on alternative measures of export sophistication. Figure 2 uses the share in exports of products defined as High-Tech in Lall (2000)'s classification. 


\section{Figure 2: China's export share of High Tech goods: evolution according to firm type}

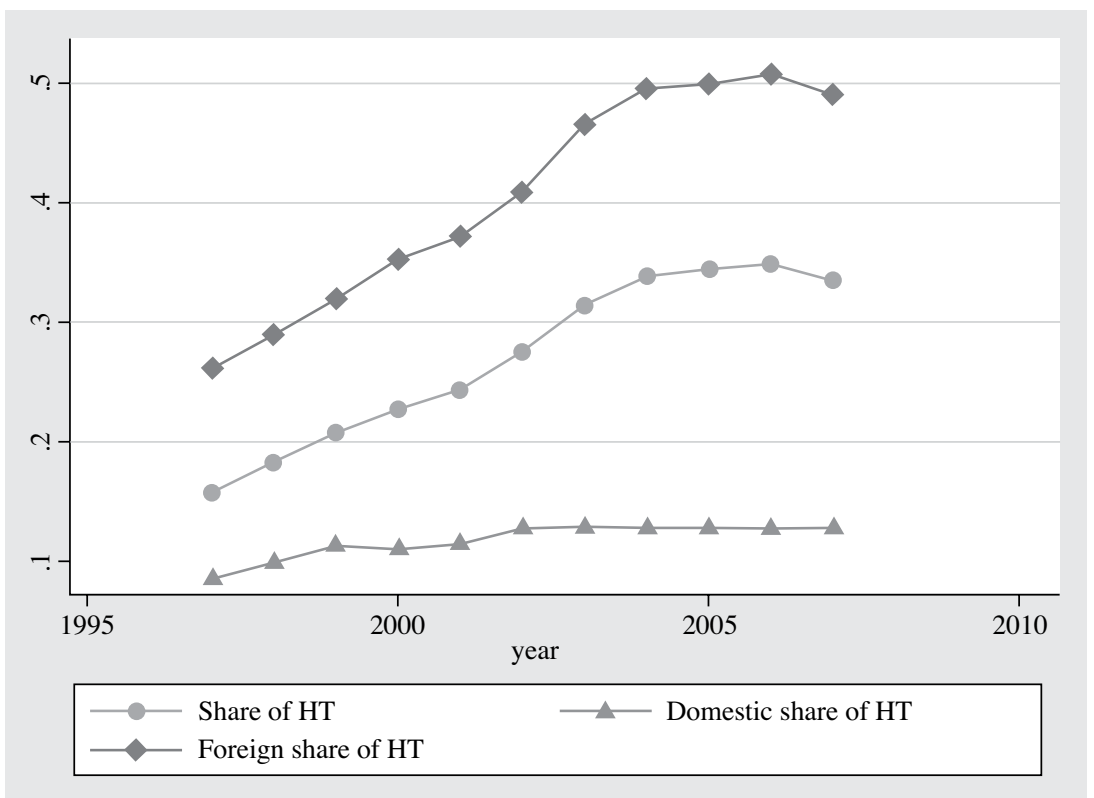

Source: Authors' computations based on Chinese customs and BACI

\subsection{Provincial heterogeneity}

We move on to look at the pattern of export sophistication across provinces in China. Chinese provinces are known to exhibit important disparities in industrial structure and in overall development; their export sophistication level is also likely to vary. One important question is whether the observed widening in economic performance is imputable to differences in export upgrading.

Figure 3 shows the relationship between real income per capita (in constant 2000 dollars) and export sophistication across provinces in 2007. The correlation is positive and varies between 0.32 and 0.68 depending on the year between these two variables in our sample of 30 provinces. We observe important disparities in terms of sophistication, with overall, the provinces where specific policies of liberalization and of openness to trade and foreign investment were put in place exhibiting some of the highest levels of export sophistication (Guangdong, Shanghai, Jiangsu, and Tianjin).

Interestingly, when looking in Figure 4 at the relationship between real income per capita and export sophistication average yearly growth rates over the period 1997-2007, we identify a much stronger correlation suggesting that the link between sophistication and growth does not simply reflect differences in terms of geography or institutions (likely to be invariant or to increase at a similar pace across China). 


\section{Figure 3: Export sophistication and real GDP per capita across China's provinces, 2007}

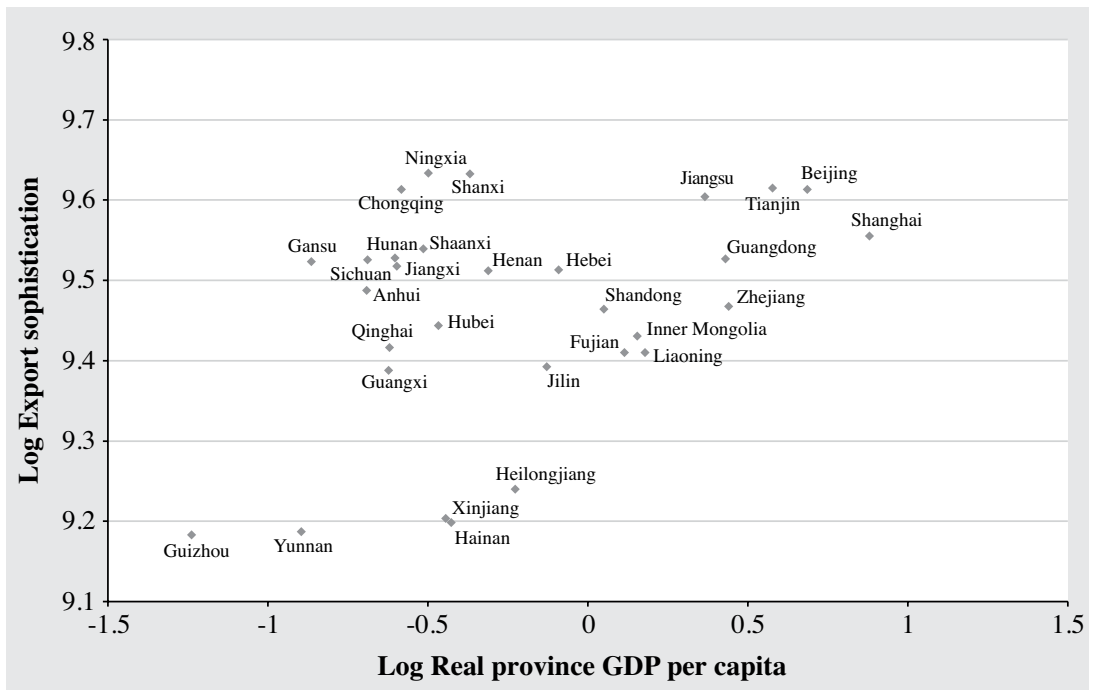

Source: Authors' computations based on Chinese customs and China Statistical Yearbooks

Figure 4: Yearly growth of export sophistication and real GDP per capita, 1997-2007

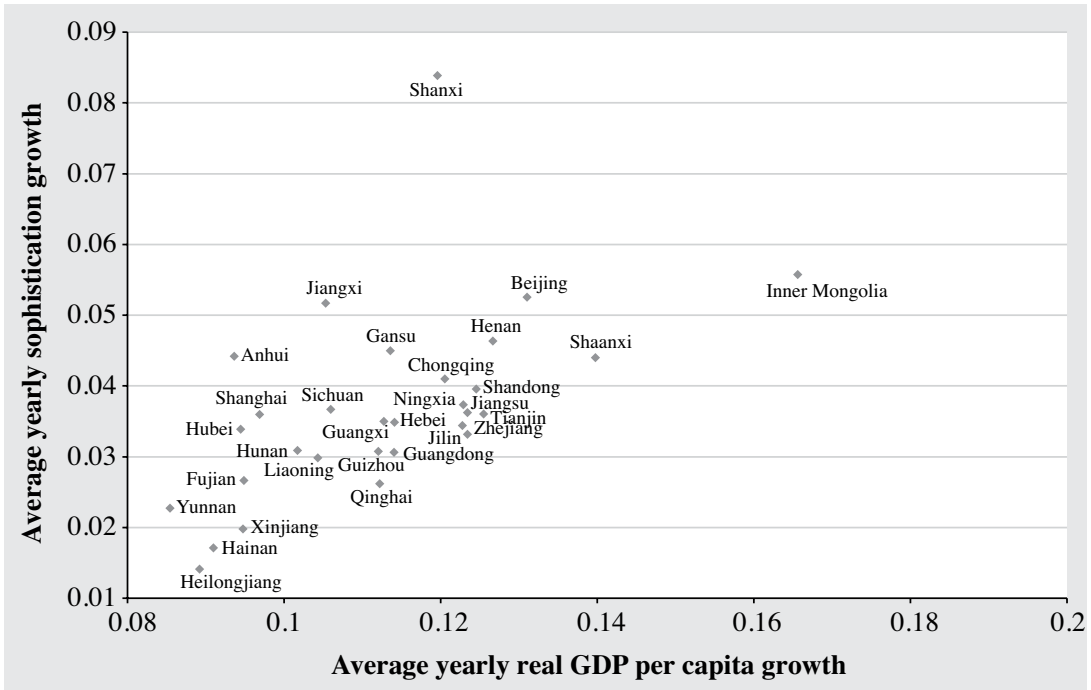

Source: Authors' computations based on Chinese customs and China Statistical Yearbooks 
In the following sections of the paper, we go further into this issue in order to verify that the observed relationship between sophistication and economic performance is truly a causal one.

\section{Econometric methodology and baseline specification}

In this section, we first present our baseline growth equation, and discuss the conditioning information set that we use. We then describe our econometric methodology.

\subsection{Baseline specification}

We use a cross-province time-series panel of data to estimate the relationship between sophistication and economic performance. We aim at testing Hausmann, Hwang and Rodrik (2007)'s prediction that regions that develop higher productivity goods grasp greater gains from globalization and have a faster economic growth. We investigate whether Chinese provinces with higher export sophistication grow faster and export more. ${ }^{6}$ Our baseline regression takes the following form:

$$
Y_{i, t}=\alpha_{1}+\alpha_{2} Y_{i, t-1}+\beta \text { Sophistication }_{i, t-1}+\gamma \text { CONTROL }_{i, t}+\eta_{i}+\mu_{t}+\varepsilon_{i, t}
$$

where $i$ indexes our 30 provinces, and $t$, time. Y denotes economic performance proxied successively by real GDP per capita and export-to-GDP ratio. Sophistication represents our indicator presented in Section 2. To make up for the potential endogeneity problems, we lag our sophistication indicator one year. We will furthermore verify, relying on instrumental variables, that our results are not biased by simultaneity or reverse causality issues. Our estimations cover 10 years from 1998 to 2007. CONTROL is defined according to the augmented Solow model as proposed by Mankiw et al. (1992). The logarithm of lagged economic performance is included to control for convergence. We also introduce the share of population with more than primary schooling as a proxy for human capital (Education) and the fixed investment over GDP ratio (Investment rate) as a proxy for physical capital accumulation. We further introduce the following four additional policy variables that have been identified in the empirical growth literature as being correlated with growth performance across countries (Barro, 1991; Easterly et al., 1997) and by Démurger (2001) and Boyreau-Debray (2003) in the Chinese context: trade as a share of GDP or FDI over GDP as a proxy for engagement in the internationalization process (outward orientation), the share of state entities in total investment (state entities) as an indicator of low progress in reform, the share of government expenditure for science and technology promotion over GDP (research expenses) to account for the investment in Research and Development, and the kilometers of railways and roads per capita (infrastructure density) as an indicator of

\footnotetext{
${ }^{6}$ We rely on annual growth rate to maximize the number of observations. Our results were robust to using two-year averages. The results based on the two-year averages are not reported for brevity, but are available on request.
} 
intra-provincial market integration. Finally, provincial fixed effects and time fixed effects are denoted by $\eta_{i}$ and $\mu_{t}$ respectively, and $\varepsilon_{i t}$ is an idiosyncratic error term.

\subsection{Econometric methodology}

The sense of the causality between export sophistication and economic performance is not clearly determined even after export sophistication is lagged one year, confronting us to a reverse causality and a simultaneity issue. We follow two alternative strategies. First we rely on internal instruments, using the Generalized-Method-of-Moments (GMM) system panel estimator, proposed by Arellano and Bond (1991) and Blundell and Bond (1998), which combines in a system the first-differenced equation with the same equation expressed in levels using appropriate lags of the right-hand side variables expressed in level and first difference as instruments. The instruments for the regression in differences are the right-hand side variables expressed in level lagged twice or more, while the instruments for the equation in levels are lagged differences of the corresponding variables. ${ }^{7}$

We will check the robustness of these results and specifically investigate the potential endogeneity issue related to our variable of interest, export sophistication, relying on external instruments in line with the literature on spillovers from foreign to domestic firms. The reliability of this method lies on the identification of instruments that are correlated with economic performance but uncorrelated with the error term, i.e. with the unobserved component of GDP per capita. Our estimations will suggest that once the export sophistication level of domestic firms is controlled for, the export sophistication level of foreign firms does not significantly affect the economic performance of a province, hence this latter variable would be a suitable instrument. We will argue that high foreign technology can benefit domestic firms in line with the empirical evidence of FDI spillovers (Javorcik, 2004; Aitken et al., 1997; Görg and Greenaway, 2004). Both instrumental procedures will provide us with coherent findings.

\section{Regression results}

\subsection{Export sophistication impact on economic growth}

Let us first focus on GDP growth as a proxy for economic performance and rely on real income per capita GDP as our dependent variable. Results are reported in Table 1. Columns (1) and (2) report our benchmark growth regression before Columns (3) and (4) add our variable of interest, province-level export sophistication.

The variables in the conditioning information set have the expected signs. Lagged GDP per capita attracts a positive and significant coefficient. The value inferior to one indicates a process of convergence. Human and physical capital accumulation generally attracts a positive and significant coefficient. Among our policy indicators, outward orientation has a positive impact on economic growth while the share of state entities in

${ }^{7}$ As discussed in Bond et al. (2001), Berg and Krueger (2004), and Hauk and Wacziarg (2004), the system-GMM is indeed the most suitable way to address the problems of estimating growth regressions. 
total investment enters with the expected negative sign. The two other control variables (research expenses and infrastructure density) do not enter significantly.

Export sophistication enters with a positive and significant coefficient. It is useful to interpret the magnitude of the estimated coefficient based on the results of Column (4). Holding other factors constant, a $15 \%$ increase in export sophistication (corresponding to a one-standard deviation over mean increase) raises income per capita by about $1.5 \%$ on average. This impact appears much greater (almost five times greater) than what Hausmann, Hwang and Rodrik (2007) estimate based on a cross-country panel data set over the period 1962-2000. It is however rather close to their results when the sample is restricted to low-middle income countries to which China belongs. Also the $1.5 \%$ growth in income per capita should be put in the context of China's rapid growth. The average per capita income growth rate is $10 \%$ over the period.

Columns (5) and (6) verify that our results are not driven by the features of some specific provinces. In Column (5) we test whether the "municipality" provinces are outliers by dropping the observations for the four "super cities" of our sample (Beijing, Tianjin, Shanghai and Chongqing). The sample size drops from 300 to 260 but leaves our results almost unchanged. We conclude that these cities do not drive the results and thus keep them in the following regressions. In Column (6) we check that our results do not derive from the two most outward-oriented provinces. Half of China's exports indeed originate from the two coastal provinces of Guangdong and Jiangsu (31 and 17\% of China's exports in 2006). Again, while our sample size drops from 300 to 280, our results are virtually unaffected.

In Column (7) we check that our results are robust to the use of first differences instead of provincial fixed effects. 


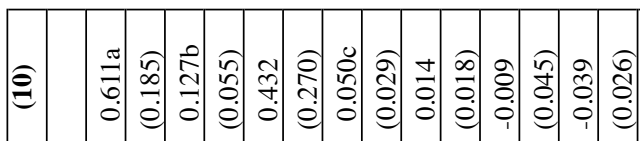

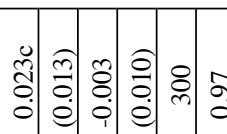

预

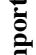

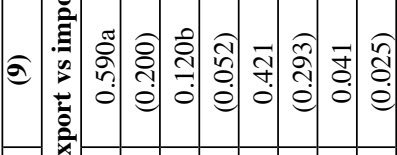

芯苍

$\because$

昜起

政

$\approx$

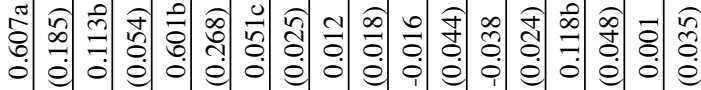

ஓి

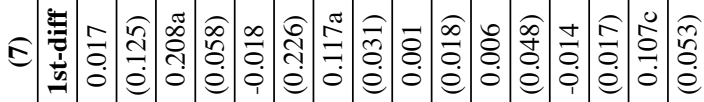

กิ

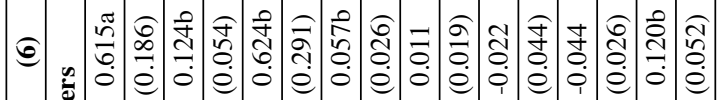

$\circ$ 造

要

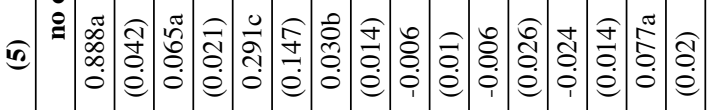

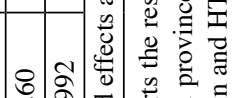
范 is क 흘

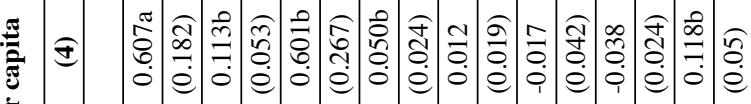
\&)

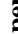

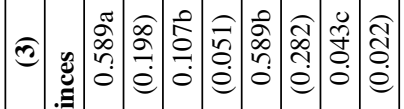

胥

ஓ̊ํ.

वे

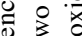

¿

ठㄹ छ

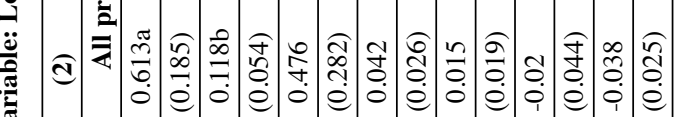

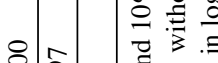

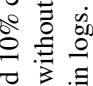

สิ 응

in

政

竝

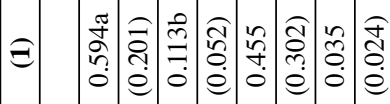

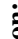

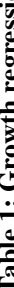

\begin{tabular}{|c|c|c|c|c|c|}
\hline 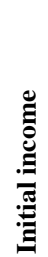 & 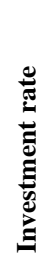 & 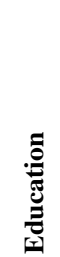 & 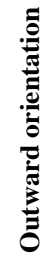 & 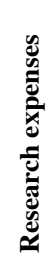 & 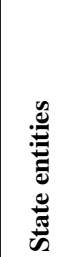 \\
\hline
\end{tabular}

窇

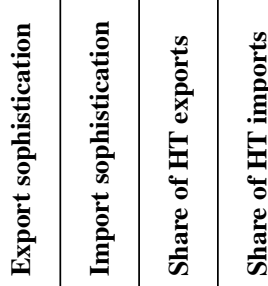

ช্ำ

क्षे

范 
The last three columns of Table 1 verify that the significant and positive contribution of export sophistication on economic performance truly pertains to the domestic ability of provinces to upgrade the sophistication of their goods and not simply to a strategy of processing trade. The issue is to which extent the measured export sophistication does not simply reflect the sophistication level of previously imported inputs.

We proceed in two steps. In Column (8) we introduce the sophistication level of imports ${ }^{8}$ in parallel to the sophistication level of exports.

The lack of significance of import sophistication and the maintained significance of export sophistication suggest that what matters for economic growth is truly the export basket sophistication and that the import basket sophistication provides no additional explanatory power. In Columns (9) and (10) we verify that we obtain similar findings using the share of high tech products in trade instead of the sophistication level. Our results tend to confirm that findings of a significant impact of export sophistication on economic growth do not simply reflect processing trade of previously imported inputs.

In China, the economic performance is thus directly connected to the development of more sophisticated goods by domestic firms despite its limited contribution to the country's global sophistication growth.

\subsection{Endogeneity issues}

We tackle the endogeneity issue in Table 2 using both internal instruments (GMM) and external instruments (2SLS). Both strategies will indicate that the exogeneity of our sophistication indicator cannot be rejected.

\footnotetext{
${ }^{8}$ It is computed in a similar manner as for exports using import shares. The sophistication level associated with a province $j$ 's import bundle (over all goods $k$ ) is obtained as $\sum_{k} \frac{\text { Import }_{j}^{k}}{\sum_{k} \text { Import }_{j}^{k}}$ PRODY
} 
Table 2: Growth regression- IV: Explained variable: Log Real GDP per capita

\begin{tabular}{|c|c|c|c|c|c|c|}
\hline & (1) & (2) & (3) & (4) & (5) & \multirow{3}{*}{$\begin{array}{c}\text { (6) } \\
\text { GMM } \\
\text { OT ver- } \\
\text { sus PCS } \\
\end{array}$} \\
\hline & FE & GMM & FE & GMM & IV & \\
\hline & \multicolumn{2}{|c|}{ Benchmark } & \multicolumn{3}{|c|}{ Domestic versus Foreign } & \\
\hline \multirow{2}{*}{ Initial income } & $0.607 \mathrm{a}$ & $0.930 \mathrm{a}$ & $0.608 \mathrm{a}$ & $0.956 a$ & $0.602 \mathrm{a}$ & $0.954 \mathrm{a}$ \\
\hline & $(0.182)$ & $(0.042)$ & $(0.182)$ & $(0.030)$ & $(0.169)$ & $(0.029)$ \\
\hline \multirow{2}{*}{ Investment rate } & $0.113 b$ & $0.068 \mathrm{~b}$ & $0.108 \mathrm{c}$ & -0.029 & $0.106 \mathrm{~b}$ & -0.026 \\
\hline & $(0.053)$ & $(0.031)$ & $(0.053)$ & $(0.044)$ & $(0.052)$ & $(0.043)$ \\
\hline \multirow{2}{*}{ Education } & $0.601 \mathrm{~b}$ & $0.347 \mathrm{c}$ & $0.618 \mathrm{~b}$ & $0.168 \mathrm{~b}$ & $0.591 \mathrm{~b}$ & $0.165 b$ \\
\hline & $(0.267)$ & $(0.186)$ & $(0.262)$ & $(0.078)$ & $(0.244)$ & $(0.079)$ \\
\hline \multirow{2}{*}{ Outward orientation } & $0.050 \mathrm{~b}$ & 0.017 & $0.052 \mathrm{~b}$ & 0.011 & $0.046 \mathrm{~b}$ & 0.012 \\
\hline & $(0.024)$ & $(0.015)$ & $(0.025)$ & $(0.012)$ & $(0.023)$ & $(0.013)$ \\
\hline \multirow{2}{*}{ Export sophistication } & $0.118 \mathrm{~b}$ & $0.047 \mathrm{c}$ & & & & \\
\hline & $(0.005)$ & $(0.027)$ & & & & \\
\hline \multirow{2}{*}{ Research expenses } & 0.012 & $0.011 \mathrm{c}$ & 0.013 & $0.015 \mathrm{a}$ & 0.021 & $0.016 \mathrm{a}$ \\
\hline & $(0.019)$ & $(0.006)$ & $(0.019)$ & $(0.005)$ & $(0.019)$ & $(0.005)$ \\
\hline \multirow{2}{*}{ State entities } & -0.017 & $-0.053 b$ & -0.019 & $-0.031 b$ & -0.020 & $-0.034 \mathrm{~b}$ \\
\hline & $(0.042)$ & $(0.021)$ & $(0.043)$ & $(0.013)$ & $(0.040)$ & $(0.013)$ \\
\hline \multirow{2}{*}{ Infrastructure density } & -0.038 & -0.011 & -0.039 & -0.010 & $-0.043 \mathrm{c}$ & -0.010 \\
\hline & $(0.024)$ & $(0.010)$ & $(0.025)$ & $(0.006)$ & $(0.025)$ & $(0.007)$ \\
\hline \multirow{2}{*}{ Domestic Export sophistication } & & & $0.108 \mathrm{c}$ & $0.055 \mathrm{~b}$ & $0.188 \mathrm{c}$ & \\
\hline & & & $(0.062)$ & $(0.027)$ & $(0.111)$ & \\
\hline \multirow{2}{*}{ Foreign Export sophistication } & & & 0.016 & 0.023 & & \\
\hline & & & $(0.023)$ & $(0.019)$ & & \\
\hline \multirow{2}{*}{ Domestic OT sophistication } & & & & & & $0.060 \mathrm{~b}$ \\
\hline & & & & & & $(0.028)$ \\
\hline \multirow{2}{*}{ Domestic PCS sophistication } & & & & & & 0.006 \\
\hline & & & & & & $(0.012)$ \\
\hline $\operatorname{AR}(2) z$ & & 1.25 & & 1.16 & & 1.15 \\
\hline Pr $>\mathbf{z}$ & & 0.213 & & 0.246 & & 0.251 \\
\hline $\begin{array}{l}\text { Overid. Restrictions test } \\
\text { Sargan } \chi^{2} \\
\text { Hansen } \chi^{2}\end{array}$ & & $\begin{array}{c}233.69 \\
16.15\end{array}$ & & $\begin{array}{c}228.06 \\
12.20\end{array}$ & & $\begin{array}{c}229.03 \\
12.82\end{array}$ \\
\hline $\begin{array}{l}\text { Davidson-Mac Kinnon } \\
\text { Exogeneity test } F(1,252) \\
\text { P-value }\end{array}$ & & & & & $\begin{array}{l}0.26 \\
0.61\end{array}$ & \\
\hline Observations & \multicolumn{6}{|c|}{300} \\
\hline R-squared & 0.970 & & 0.970 & & 0.970 & \\
\hline
\end{tabular}

$\mathrm{a}, \mathrm{b}$ and $\mathrm{c}$ indicate significance at the $1 \%, 5 \%$ and $10 \%$ confidence level. All indicators (except education) are in logs. Proxies of trade sophistication are lagged by one year in fixed effects regressions. In columns 1 and 3 sophistication indicators are not instrumented but are lagged by one year. Columns 2, 4 and 6 report the results relying on the GMM system estimator. The validity of this procedure is not rejected based on the non significance of the autocorrelation of errors and the non significance of the Hansen and Sargan tests of overidentifying restrictions. Column 5 reports the results relying on instrumental variables. Domestic export sophistication is instrumented by the contemporary and the lagged non-domestic export sophistication. The validity of these instruments is not rejected. Both variables enter positively and significantly in the first stage regression for which the partial $R^{2}$ is $10 \%$ and the F-test of excluded instruments is $\mathrm{F}(2,29)=13.51$. The Hansen test of overidentifying restrictions is not rejected $(2.3$, Chi-sq(1) P-val $=0.13)$. The Kleibergen-Paap rk Wald F-stat is 13.5. The Davidson-MacKinnon test of exogeneity is not rejected $(F(1,252)=0.059$, p-value $=0.81$ ). 
The consistency of the GMM estimates (Columns (2), (4) and (6)) will be checked based on the two tests suggested by Arellano and Bond (1991) and reported at the bottom of the Table. The test for second-order serial correlation of the residuals (AR(2)) indicates that the orthogonality conditions cannot be rejected at the one percent level, thus that the error term is not serially correlated. The Hansen and Sargan tests for overidentifying restrictions both do not reject the null hypothesis that our instruments are appropriate.

The comparison of Columns (1) with fixed effects and (2) with GMM allows us to identify that GMM estimators confirm the positive impact of export sophistication on economic growth. The next three columns of Table 2 address the endogeneity of our variable of interest more precisely and develop an instrumentation strategy based on external instruments for our indicator of export sophistication. Based on fixed effects and GMM estimators, respectively, Columns (3) and (4) investigate the relative importance of domestic and foreign export sophistication. The two non-overlapping indicators are computed using the Hausmann, Hwang and Rodrik (2007) procedure (described in Section 2.1) on export flows of domestic and foreign firms separately. Results in both columns indicate that once the export sophistication level of domestic firms is controlled for, the export sophistication level of foreign firms does not significantly affect the economic performance of a province. The absence of a direct effect of the productivity of the foreign firms export basket on economic growth once that of domestic firms is taken into account suggests a possible instrumentation strategy based on the hypothesis of productivity spillovers from foreign to domestic firms. Several channels are put forward theoretically to explain that foreign firms can benefit innovation activity of domestic firms. A first channel corresponds to reverse engineering. A second channel is via skilled labor turnovers. A third spillover channel corresponds to a demonstration effect on local R\&D activity. A final spillover channel emphasized by Javorcik (2004) is through supplier-customer relationships. Several studies provide empirical support for these FDI spillover effects (Blomstrom and Kokko, 1999). In the specific context of China, Hu and Jefferson (2001) and Cheung and Lin (2004) find evidence of a positive effect of FDI on the performance of domestic firms.

Column (5) reports the results of our two-stage instrumentation strategy. The first stage corresponds to the regression of the domestic export sophistication on the contemporaneous and lagged foreign export sophistication as well as the other explanatory variables of income performance considered in Equation 3. The traditional tests (first stage $R^{2}$, Hansen test of overidentifying restrictions and the weak identification test) suggest the validity of the procedure. Our result confirms previous evidence that the positive relationship between export sophistication and growth is not biased by endogeneity problems.

Our findings so far suggest that the positive effect of export sophistication on growth reflects the direct positive impact of the productivity of the export basket demonstrated by domestic firms (and not foreign firms) on growth. The first stage results of the IV regression nevertheless suggests that while China's policy of opening to foreign investment did not bring direct growth enhancing effects, some benefits were realized as technological capabilities spilled over to domestic producers. 
A remaining issue to be investigated is whether the impact pertains to ordinary trade export or processing trade. This is the focus of the last column of Table 2. The GMM estimator is applied to a specification that decomposes the export sophistication into its ordinary trade (OT) and processing (PCS) trade components. The two nonoverlapping indicators simultaneously enter with a positive sign but only ordinary trade sophistication is significant (at the 5\% confidence level). This confirms the results obtained in the last three columns of Table 1 . The significant impact of export sophistication on economic growth mainly corresponds to the positive effect of technological capabilities demonstrated by domestic firms. Direct gains do not appear to derive from processing trade activities.

\subsection{Export sophistication impact on export performance}

We now turn to our second proxy of economic performance, the export rate. Rodrik (2006) suggest that China's capacity to export a bundle of goods much similar to that exported by countries three times richer in per capita terms has been the key to its successful export growth. We thus expect that within China, provinces with higher export sophistication gain more from trade and thus export more. We estimate Equation 3 relying on the export to GDP ratio as our dependent variable. Results are reported in Table 3. Outward orientation is proxied by the ratio of FDI over GDP. The first eight columns run estimations similar to the first eight columns of Table 1. Columns (1) and (2) display the benchmark export performance regressions before introducing our indicators of export sophistication in Columns (3) and (4). 


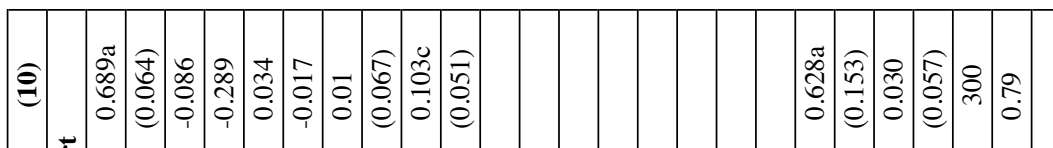

ล)

(2)

这

क्ष

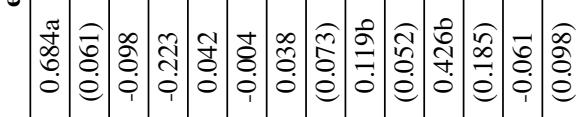

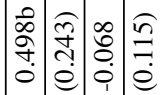

\&

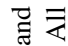

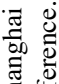

萦离

害范

$\stackrel{\pi}{*} . \Xi$

船

๑ृ.

\&্ল

象

:

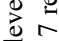

E

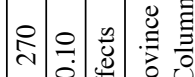

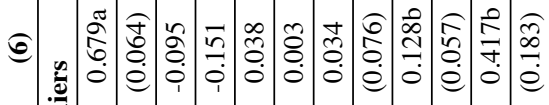

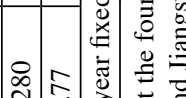

ㄴ.

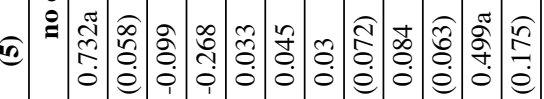

(3)

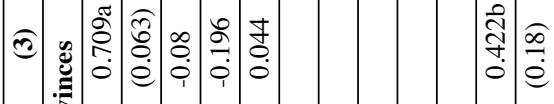

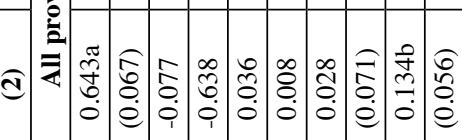

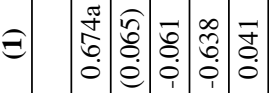

\&

৪)

究

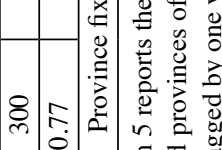

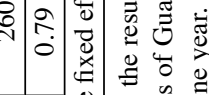

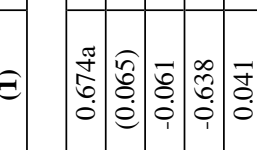

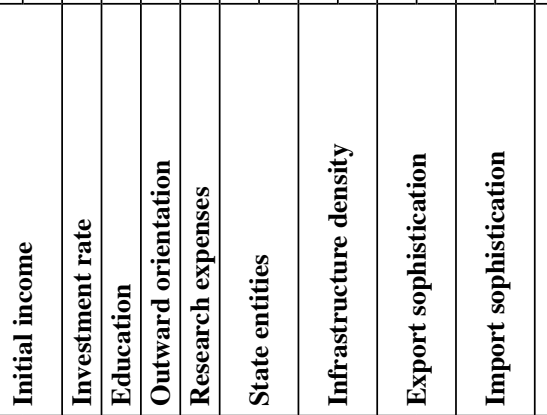

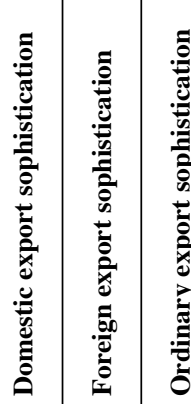



节总离

ن

एं

党产

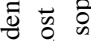

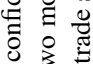

$\therefore \underbrace{3}$

:

氶 言

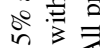

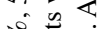

过泀 
While the explanatory power of the regressions appears high (the within $\mathrm{R}^{2}$ is above $75 \%$ ), it is mostly due to the lagged dependent variable. The initial export to GDP rate attracts a significant and positive (but lower than 1) coefficient. The two proxies for human and physical capital accumulation fail to enter significantly. Among our control variables, most are not significant. ${ }^{9}$ The only exception is the proxy for infrastructure density that enters with a positive and highly significant coefficient.

Our variable of interest, export sophistication enters with a positive and significant coefficient. Results in our preferred specification (Column (4)) suggest that holding other factors constant, a $10 \%$ increase in export sophistication raises export rate by about $4 \%$ on average. Since the average export-to-GDP rate in China is $20 \%$, this impact is clearly economically significant. This impact proves robust to the two checks run in Columns (5) and (6), i.e. the exclusion of the four "super cities" and of the two most outward-oriented coastal provinces of Guangdong and Jiangsu, respectively. Our results also remain when first differences estimators are used instead of provincial fixed effects (Column (7)).

An important question in the Chinese context is again the origin of this cost discovery process. It is crucial to determine whether it matters that it is undertaken by domestic entities and whether the discovery can be imported notably through FDI or trade processing.

Estimates obtained above on the impact of export sophistication on economic growth (columns 8 to 10 of Table 1) already suggest that sophistication induced economic performance in China does not simply reflect a strategy of technology acquisition through the processing of previously imported inputs and the attraction of foreign entities. We indeed observed that what matters for economic performance are sophistication efforts undertaken by domestic firms for trade. We verify these results looking at trade performance in the last three columns of Table 3. In Column (8), we introduce the sophistication level of imports in parallel to the sophistication level of exports.

In coherence with results obtained on GDP per capita, import sophistication does not enter significantly, suggesting that the positive impact of the productivity of the export basket does not simply reflect the importance of assembly trade. Columns (9) and (10) decompose sophistication between its domestic and foreign components and between its ordinary trade and processing trade components respectively. The measured lack of significance of the foreign and processing trade sophistication, once the domestic or ordinary export sophistication is controlled for, further confirms the importance of domestic development of more sophisticated goods for trade and economic performance. Technology acquisition from the processing of previously imported inputs and the attraction of foreign entities seems to be beneficial to growth only to the extent that they are fully taken over by domestic firms.

\footnotetext{
${ }^{9}$ The standard errors for non significant variables are not reported for the sake of space saving.
} 


\section{Conclusion}

In this article, we rely on regional variations within a single country (China), to investigate whether export sophistication is growth enhancing. We verify Hausmann, Hwang and Rodrik (2007)'s prediction that regions that engage in the cost discovery process of developing higher productivity goods grasp greater gains from globalization and have a faster economic growth. We find that these gains are limited to activities undertaken by domestic entities. Economic performance is thus directly connected to the cost discovery process of developing higher productivity by domestic firms despite its limited contribution to the global sophistication growth. Direct gains do not appear to derive from foreign entities typically engaged in processing trade even though China's policy of opening to foreign investment is beneficial through the indirect channel of technology spillovers from foreign to domestic firms.

\section{References}

Aitken B. J., G. Hanson and A. Harrison, 1997, "Spillovers, foreign investment and export behavior", Journal of International Economics, 43, 103-132.

Arellano M. and S. Bond, 1991, "Some tests of specification for panel data: Monte Carlo evidence and an application to employment equations", Review of Economic Studies, 58, 277-297.

Amiti M. and C. Freund, 2008, “An Anatomy of China’s Export Growth”, NBER Policy Research working paper 4628.

Barro R., 1991, "Economic growth in a cross-section of countries", Quarterly Journal of Economics, 56, 407-443.

Berg A. and A. Krueger, 2003, "Trade, growth and poverty: a selective survey". IMF Working Paper No. 03/30.

Blundell R. and S. Bond, 1998, "Initial conditions and moment restrictions in dynamic panel data models", Journal of Econometrics, 87, 115-143.

Blomstrom, M., and A. Kokko, 1998, "Multinational corporations and spillovers", Journal of Economic Surveys, 12(3), 247- 278.

Bond S., C. Bowsher and F. Windsmeijer, 2001, "Criterion-based inference for GMM in autoregressive panel data models", Economics Letters, 73, 379-388.

Boyreau-Debray G., 2003, "Financial intermediation and growth: Chinese style”. World Bank Policy Research Working Paper No. 3027.

Cheung, K.-Y, and P. Lin, 2004, "Spillover effects of FDI on innovation in China: evidence from the provincial data", China Economic Review 15 (1), 25-44.

Démurger S., 2001, "Infrastructure Development and Economic Growth: an Explanation for Regional Disparities in China?", Journal of Comparative Economics 29, 95117.

Easterly W., N. Loayza and P. Montiel, 1997, "Has Latin America's post reform growth been disappointing?" Journal of International Economics, 43, 287-311.

Fujita M., P. Krugman and A. J. Venables, 1999, The Spatial Economy: Cities, Regions, and International Trade, Cambridge, MA, MIT Press. 
Gaulier G. and S. Zignago, 2008, "BACI: A World Database of International Trade at the Product level, 1995-2004 version”, CEPII working paper.

Görg H. and D. Greenaway, 2004, "Much Ado About Nothing? Do Domestic Firms Really Benefit from Foreign Direct Investment?", World Bank Research Observer, 19, 2, 171-97.

Hausmann R., J. Hwang and D. Rodrik, 2007, "What You Export Matters", Journal of Economic Growth, 12, 1-25.

$\mathrm{Hu}$, A., and G. Jefferson, 2001, "FDI, technological innovation, and spillover: Evidence from large and medium size Chinese enterprises", mimeo. Brandeis University: Waltham, MA.

Javorcik S. B., 2004, "Does Foreign Direct Investment Increase the Productivity of Domestic Firms? In Search of Spillovers through Backward Linkages", American Economic Review, 94, 3, 605-27.

Lall S., 2000, "The Technological Structure and Performance of Developing Country Manufactured Exports, 1985-1998”, Oxford Development Studies, 28, 3.

Lall S., J. Weiss and J. Zhang, 2006, “The 'Sophistication' of exports: a new trade measure", World Development, 34 (2), 222-237.

Lemoine F. and D. Unal-Kesenci, 2004, Assembly Trade and Technology Transfer: the case of China', World Development, 32, 5, 829-850.

Rodrik D., 2006, "What is so special about China's Exports?", China \& World Economy, $14(5), 1-19$.

Wang Z. and S.-J. Wei, 2010, "What accounts for the rising sophistication of China's exports", chapter in Feenstra, R. and S-J. Wei (eds.), China's Growing Role in World Trade, University of Chicago Press. 
